2. Винницкий, С., Романюк, В., \& Савиных, П. (2014). Эффективность применения доильных роботов на семейных фермах Польши. Аграрная наука Евро-Северо-Востока, 4, 52-56.

3. Бугай, Т.А., \& Гноєвий, І.В. (2020). Передумови роботизації процесу доїння корів. Вісник Сумського національного аграрного університету, № 1, С. 30-36.

DOI https://doi.org/10.30525/978-9934-26-111-4-61

\title{
ГОРМОНАЛЬНІ ЗМІНИ В ОРГАНІЗМІ ТЕЛИЦЬ ПІСЛЯ ЗАСТОСУВАННЯ КОМПЛЕКСІВ НАНОКАРБОКСИЛАТІВ ДЛЯ СТИМУЛЯЦІї РЕПРОДУКТИВНОЇ ФУНКЦІї
}

\author{
Хоменко М. О. \\ кандидат сільськогосподарських наук, \\ асистент кафедри генетики, розведення та біотехнології тварин \\ Національний університет біоресурсів і природокористування Украйни \\ м. Київ, Украӥна
}

Порушення відтворювальної здатності у корів $є$ на сьогоднішній день дуже складною і надзвичайно актуальною проблемою у тваринництві. У більшості господарств для підвищення заплідненості корів та лікування гінекологічних патологій застосовують гормональні препарати, які можуть справляти на організм тварин як позитивний, так i негативний вплив. Зі зростанням попиту на органічну продукцію відповідно зростає кількість господарств, які займаються таким виробництвом, і де існують обмеження щодо застосування великої кількості зооветеринарних препаратів, зокрема і гормональних.

У зв'язку з цим розробка нових негормональних біологічних препаратів та біотехнологічних способів їх застосування, що будуть спрямовані на стимуляцію відтворювальної здатності самок сільськогосподарських тварин без негативного впливу на їхнє здоров'я, $€$ досить актуальним напрямом.

3 розвитком нанотехнології стало можливим створення мікроелементів у нових формах, які мають ширший спектр дії та нові властивості, що не притаманні солям мікроелементів. Оскільки, нанокарбоксилати створені не хімічним, а фізичним способом, вони повністю засвоюються організмом і проявляють високий стимулюючий ефект на біологічні процеси в організмі. 
Відомо, що перебіг тільності характеризується співвідношенням концентрації стероїдних гормонів, які впливають на характер родового акту і післяродового періоду [5, 8]. Уміст та співвідношення статевих гормонів у крові змінюється залежно від фізіологічного стану [1]. Прогестерон та естрадіол справляють найбільший вплив на перебіг вагітності. На статевий апарат самки ці гормони проявляють як синергічну так і антогонічну дію. Наприклад, естрадіол стимулює скорочення матки, його вміст підвищується у період приживлення, що може негативно вплинути на імплантацію ембріона, тоді як зростання рівня прогестерону в цей період, навпаки, пригнічує скорочення матки i позитивно впливає на процес імплантації. Синергічна дія даних гормонів полягає в тому, що естрогени підготовлюють матку до подальшого впливу прогестерону [4, 7].

Дослід з визначення гормонального фону тварин було проведено на телицях української чорно-рябої породи, живою масою 300-320 кг. Групи формувалися методом пар-аналогів за породою, віком, живою масою та фізіологічним станом. Телиць у групи відбирали після синхронізації в них охоти за допомогою препарату естрофан. Після приходу в охоту тварини осіменялися ректоцервікальним способом. Телицям контрольної групи уводили фізіологічний розчин натрію хлориду; I-й дослідній - $\mathrm{Se}, \mathrm{Cu}, \mathrm{Mn}, \mathrm{Cr}$; II-й $\mathrm{Ge}, \mathrm{Cu}, \mathrm{Mn}, \mathrm{Cr}$ та $\mathrm{Se}$; тваринам III-ї дослідної групи уводили $\mathrm{Ge}, \mathrm{Cu}, \mathrm{Mn}$ та $\mathrm{Cr}$. Препарати ін'єктували на 10-12-й -й день статевого циклу підшкірно за лопаткою у дозі 0,02 мл/кг.

Кров відбирали на 9-й та 13-й день статевого циклу, вранці перед годівлею з хвостової вени у спеціальні пробірки для відбору крові.

Уміст прогестерону, естрадіолу та тестостерону визначали в сироватці крові, яку отримували після природного зсідання шляхом центрифугування протягом 15 хв. Отримані зразки сироватки відразу заморожували в рідкому азоті у полістиролових пробірках об'ємом 2,5 мл. Концентрацію гормонів визначали у медичній лабораторії Аналітика у м. Харків. Дослідження проводили імунохемілюмінесцентним (IXЛ) методом на автоматичному аналізаторі закритого типу Bioscience AIA-600 компанії TOSOH (Японія) 3 використанням оригінальних японських реактивів згідно 3 інструкцією (Автоматический анализатор, 2013).

У тварин, в яких визначали гормональні зміни, рівень заплідненості становив: у контрольній групі - $40 \%$, у І дослідній - $60 \%$, у II - $80 \%$, у III дослідній групі - 60 \%. 
Проаналізувавши динаміку концентрації (табл. 1) прогестерону з 9 по 13 день після осіменіння, можна твердити, що вміст цього гормону у крові корів усіх чотирьох груп зростає. У контрольній групі на 13 день рівень прогестерону підвищився на 8,6 \%, у першій дослідній - на 10,4 $\%$, у другій та третій групах, відповідно, - на 20,3\% (p<0,05) та $18,7 \%$ $(\mathrm{p}<0,05)$. Як бачимо, істотно рівень прогестерону зріс у другій групі, у цій групі виявилося найбільше тільних корів.

Таблиця 1

Уміст гормонів у крові піддослідних телиць

\begin{tabular}{|c|c|c|c|c|c|c|}
\hline \multirow[b]{2}{*}{ Група } & \multicolumn{2}{|c|}{ Прогестерон, нг/мл } & \multicolumn{2}{|c|}{ Естрадіол, пг/мл } & \multicolumn{2}{|c|}{$\begin{array}{c}\text { Тестостерон, } \\
\text { нг/мЛ }\end{array}$} \\
\hline & 9 день & 13 день & 9 день & 13 день & 9 день & 13 день \\
\hline $\begin{array}{c}\text { Контрольн } \\
\text { a } \\
\text { n=5 }\end{array}$ & $\begin{array}{l}3,28 \pm \\
0,381\end{array}$ & $\begin{array}{l}3,59 \pm \\
0,554\end{array}$ & $\begin{array}{c}17,08 \pm \\
1,659\end{array}$ & $\begin{array}{c}16,84 \pm \\
0,863\end{array}$ & $\begin{array}{l}3,16 \pm \\
0,328\end{array}$ & $\begin{array}{l}3,21 \pm \\
0,265\end{array}$ \\
\hline $\begin{array}{c}\mathrm{I} \text { дослідна } \\
\mathrm{n}=5\end{array}$ & $\begin{array}{l}3,36 \pm \\
0,275\end{array}$ & $\begin{array}{l}3,75 \pm \\
0,441\end{array}$ & $\begin{array}{c}16,71 \pm \\
1,303\end{array}$ & $\begin{array}{c}16,28 \pm \\
1,237\end{array}$ & $\begin{array}{l}3,13 \pm \\
0,441\end{array}$ & $\begin{array}{l}3,20 \pm \\
0,301\end{array}$ \\
\hline $\begin{array}{c}\text { II дослідна } \\
\text { n=5 }\end{array}$ & $\begin{array}{l}3,26 \pm \\
0,256\end{array}$ & $\begin{array}{c}4,09 \pm \\
0,254^{*}\end{array}$ & $\begin{array}{c}16,89 \pm \\
1,353\end{array}$ & $\begin{array}{c}16,40 \pm \\
1,167\end{array}$ & $\begin{array}{l}3,29 \pm \\
0,693\end{array}$ & $\begin{array}{l}3,29 \pm \\
0,572\end{array}$ \\
\hline $\begin{array}{c}\text { III } \\
\text { дослідна } \\
\mathrm{n}=5\end{array}$ & $\begin{array}{l}3,28 \pm \\
0,319\end{array}$ & $\begin{array}{c}3,95 \pm \\
0,691^{*}\end{array}$ & $\begin{array}{c}16,75 \pm \\
1,466\end{array}$ & $\begin{array}{c}16,27 \pm \\
0,969\end{array}$ & $\begin{array}{l}3,24 \pm \\
0,480\end{array}$ & $\begin{array}{l}3,28 \pm \\
0,520\end{array}$ \\
\hline
\end{tabular}

Примітка. *p<0,05 до показника 9-го дня

Основним і найбільш активним естрогеном є естрадіол, який, як $\mathrm{i}$ інші гормони, синтезується з холестерину, а проміжним продуктом $\epsilon$ тестостерон [2]. Концентрація естрадіолу на початку та до середини тільності є низькою і зростає перед отелом [5, 9]. 3 результатів дослідження видно, що динаміка концентрації естрадіолу, навпаки, 3 дев'ятого по тринадцятий день має тенденцію до зниження: $\mathrm{y}$ контрольній групі - на $1,4 \%$, у першій, другій та третій дослідних групах - на 2,5\%; 2,9 \% та 2,8 \%, відповідно.

Наступним гормоном, уміст якого визначали в сироватці крові телиць, був тестостерон. У самок цей гормон та його попередники синтезуються у значно меншій концентрації, ніж у самців. У яєчниках тестостерон перетворюється в естроген [2]. Аналіз показників концентрації тестостерону у крові телиць свідчить, що у контрольній, першій та третій групах на 13-й день після осіменіння спостерігалося незначне підвищення вмісту цього гормону, яке коливалося в межах 2 \%. У другій дослідній групі цей показник не зазнав змін. 
Для кращого аналізу порівняли показник умісту гормонів між групами на 13-й день статевого циклу. Рівень прогестерону у контрольній групі з дев'ятого по тринадцятий день підвищився на 8,6 $\%$, у першій дослідній - на $10,4 \%$, у другій - на 20,3\% $(\mathrm{p}<0,05)$, у третій - на 16,9 \%. Найвищий вміст прогестерону був у крові корів другої групи, він становив 4,09 нг/мл, що на 12,2 \% перевищувало показники контрольної групи та на 8,3 \% і 3,4%, відповідно, першої і третьої дослідної груп. Завдяки зростанню концентрації прогестерону в цей період знижується збудливість біометрію та пригнічується його скоротлива активність. Крім того, цей гормон блокує імунну відповідь материнського організму на ембріон і тим самим створює сприятливі умови для розвитку зародка. Про це можуть свідчити і показники заплідненості у другій групі [3]. Як видно з наведених даних, у сироватці крові піддослідних телиць концентрація естрадіолу у всіх чотирьох групах мала незначні відхилення - в межах $3 \%$.

Отже, можна дійти висновку, що нанокарбоксилати стимулюють синтез прогестерону та сприяють імплантації ембріона в ендометрій матки. Також, 3 отриманих результатів видно, що мікроелементи справляють незначний вплив на уміст естрадіолу. Проведені дослідження також показали, що показники концентрації тестостерону у досліджуваний період по всіх групах мали незначну різницю.

\section{Література:}

1. Власенко С. А. Статеві стероїди у крові корів протягом репродуктивного циклу за гнійно-некротичних уражень в ділянці пальців. Біологія тварин. 2015. Т. 17. № 4. С. 9-17

2. Гонський Я. І. Максимчук Т.П. Біохімія людини. Тернопіль: Укрмедкнига, 2011.736 с.

3. Себа Н. В., Дейнека М. О. Влияние препарата «Кватронан-Sе» на воспроизводительную способность и гематологические показатели крови коров симментальской породы. Актуальные проблемы интенсивного развития животноводства: XIX Международная научнопрактическая конференция, г. Горки, Республика Беларусь, 1-3 июня 2016 года: тезисы доклада. Горки. 2016. Ч. 2. С. 252-256.

4. Фізіологія тварин:підручник. Мазуркевич А. Й. та ін. Вінниця: Нова Книга, 2012. 424 с.

5. Юрдін Ю. Плахотнюк I. Ендокринний профіль крові корів за норми та акушерської патології. Матеріали конференції. 2015. № 10. C. $20-21$. 
6. Яблонський В. А. Біотехнологія відтворення тварин. К: Арістей, 2004. 293 c.

7. Bouman A., Heineman M. J., Faas M. M. Sex hormones and the immune response in humans. Human Reproduction Update. 2005. Vol. 11. №4. P. 411-423.

8. Mann G.E. Corpus luteum size and plasma progesterone concentration in cows. Animal Reprod. Sci. 2009. Vol. 115. P. 296-299.

9. Spicer L.J., Zinn S.A. Relationship between concentrations of cortisol in ovarian follicular fluid and varions biochemical markers of follicular differ-entiation in cyclic and anovulatory cattle. J. Animal Sci. 2006. Vol 2. P. 2001-2017.

DOI https://doi.org/10.30525/978-9934-26-111-4-62

\section{МІКОТОКСИНИ У ЗЕРНІ ЗЛАКОВИХ КУЛЬТУР ТА НЕОБХІДНІСТЬ ЇХ КОНТРОЛЮ}

\section{Чорнолата Л. П.}

кандидат сільськогосподарських наук, старший науковий співробітник, завідувач лабораторії моніторингу якості, безпеки кормів та сировини

Інститут кормів та сільського господарства Поділля

Національної академії аграрних наук Украӥни

\section{Гуцол Н. В.}

кандидат сільськогосподарських наук, старший науковий співробітник лабораторії моніторингу якості, безпеки кормів та сировини Інститут кормів та сільського господарства Поділля Національної академії аграрних наук України

\section{Мисенко О. О.}

кандидат сільськогосподарських наук, старший науковий співробітник лабораторії моніторингу якості, безпеки кормів та сировини Інститут кормів та сільського господарства Поділля Національної академії аграрних наук України м. Вінниця, Україна

Злакові зернові корми містять невелику кількість сирого протеїну (55-80г на 1 кормову одиницю). Основна маса їх сухої речовини 